\title{
Człowiek w płomieniach. Mityczna wyobraźnia Artura Pałygi
}

Jacek Kopciński

TEKSTY DRUGIE 2020, NR 6, S. 279-294

DOI: 10.18318/td.2020.6.16 | ORCID: 0000-0002-5347-9006

$\mathrm{P}_{\mathrm{t}}^{o}$ owrót bogów - taki intrygujący tytuł nosi tom sztuk teatralnych Artura Pałygi wydany w 2017 roku w serii „Nasze Dramaty”. W skład wyboru dokonanego przez samego autora weszło pięć utworów: Nieskończona historia, W środku stońca gromadzi się popiót, tytułowy Powrót bogów, Znak Jonasza i $W$ promieniach. Dramaty pierwszy, drugi i czwarty znalazły się na teatralnym afiszu (nawet kilkukrotnie, z wyjątkiem Znaku Jonasza), co jest sporym osiągnięciem w czasach, gdy wyobraźnia reżysera liczy się na scenie bardziej niż wyobraźnia autora. Dramaty pierwszy, drugi i piąty były drukowane, a nawet komentowane w „Dialogu”, i to także należy zaliczyć do sukcesów Pałygi, choć wpływ tego miesięcznika na współczesną humanistykę nie jest już taki jak dawniej. Mimo premier i publikacji poszczególnych utworów cały tom zdeprymował recenzentów i nie doczekał się szerszego omówienia. Winić za to można nie tylko krytykę, niechętną współczesnej dramaturgii i raczej bezradną wobec niej, ale też samego autora, który w Powrocie bogów nie ogłosił swoich najbardziej znanych sztuk, sięgnął natomiast po te najbardziej oryginalne.

Jacek Kopciński historyk literatury, krytyk teatralny, redaktor naczelny miesięcznika "Teatr". W Instytucie Badań Literackich PAN kieruje Ośrodkiem Badań nad Polskim Dramatem Współczesnym. Jest autorem monografii Gramatyka i mistyka. Wprowadzenie w teatralnq osobność Mirona Białoszewskiego (1997) oraz Nasłuchiwanie. Sztuki na głosy Zbigniewa Herberta (2008), dwóch tomów szkiców teatralnych (Którędy do wyjścia?, 2002), Powrót „Dziadów", 2016). Wydał tom interpretacji polskich dramatów współczesnych Wybudzanie (2018), opracował antologię Transformacja.

Dramat polski po 1989 roku. Pomysłodawca i redaktor naukowy serii „Dramat Polski. Reaktywacja". 


\section{Historia imit}

Pałyga to dramatopisarz o dwóch biografiach artystycznych i dwóch twórczych osobowościach, które tylko czasem integrują się w szczęśliwym zdarzeniu teatralnym. W 2006 roku debiutował tekstem Testament Teodora Sixta. Ta wielowątkowa sztuka, poświęcona historycznym mieszkańcom Bielska-Białej, została wystawiona w tamtejszym Teatrze Polskim przez Roberta Talarczyka. Na zamówienie tego samego reżysera dwa lata później powstała jednoaktówka $\dot{Z} y$ d. Jej akcja rozgrywa się współcześnie, w typowym pokoju nauczycielskim, gdzie dyrektor i kilkoro pedagogów obmyśla plan przyjęcia dawnego ucznia - a obecnie obywatela Izraela - zdradzając przy tym mnóstwo stereotypowych przekonań na temat Żydów. Lista utworów Pałygi napisanych na zamówienie teatrów i konkretnych reżyserów jest dłuższa. Podejmując proponowane tematy: rodziny tyranizowanej przez ojca - oficera Ludowego Wojska Polskiego (Ostatni taki ojciec), ataku polskich żołnierzy na ludność cywilną w Nangar Khel (Nangar Khel. Postscriptum) czy straceńczych rajdów w bydgoskim klubie żużlowym (Szwoleżerowie), pisarz współpracował z Piotrem Ratajczakiem, Łukaszem Witem-Michałowskim, Janem Klatą. Z tekstów, które napisał dla tych reżyserów, już dawno mógłby złożyć osobny tom - jednak nigdy tego nie uczynił.

Jedynie współpraca z Pawłem Passinim, uzdolnionym reżyserem nurtu niezależnego, pozwala mu bowiem utrzymać w teatrze autorski styl, oryginalną poetykę, a przede wszystkim własną optykę. Świadczy o tym pomieszczony w omawianym tomie ZnakJonasza, zainscenizowany przez Passiniego podczas Festiwalu Nowe Epifanie w 2016 roku. Osią fabularną tego nowoczesnego dramatu liturgicznego są dwie opowieści biblijne: midrasz o człowieku, którego połknęła „wielka ryba” (w Starym Testamencie to Księga Jonasza), i ten fragment Ewangelii, w którym trzy Marie nawiedzają Grób Pański. Kiedy bowiem Pałyga nie pisze na zamówienie, porzuca historię (i historie) na rzecz opowieści o charakterze mitycznym, a bohaterami swoich utworów czyni obok najzwyklejszych mieszkańców bloku - herosów z dawnych mitologii, bohaterów Starego i Nowego Testamentu, antycznych wodzów i filozofów, Boga Żydów i chrześcijan czy zapomniane bóstwa pierwotne, które w dramacie Powrót bogów zjawiają się pod postacią zwierząt, roślin, a nawet drobnoustrojów. Piękne, łacińskie nazwy bakterii (np. Pseudomonas Aeruginosa) to jedyny ukłon Pałygi w stronę klasycznej tradycji literackiej. Autor Powrotu bogów uprawia dramat poetycki tak, jak czynili to jego poprzednicy - Wyspiański i Herbert - a więc na ustanowionych przez siebie zasadach i w celu, którego nie jest w stanie zrealizować martwa sztuka stylizacji. „W zebranych 
tu dramatach bogowie wracają sprzed przeszłości, nie z tradycji czy z historii, ale z zasypanego źródła ludzkiej potrzeby obcowania z nieludzkim"1 - czytamy na skrzydełku książki w krótkiej notce, nawet jeśli nie napisanej ręką autora, to na pewno przez niego zaakceptowanej. Ten celny komentarz odsłania nie tylko sens dramatycznych praktyk Pałygi, ale także trop jego lektur podstawowych, do których zaliczam pisma Mircei Eliadego.

Wydaje się, że to właśnie dorobek rumuńskiego uczonego miał decydujący wpływ na kształtowanie się mitycznej wyobraźni Pałygi w czasach, gdy uprawiał on jeszcze dziennikarstwo, a nie poezję, która rodzi się w działaniu². Myślę tu przede wszystkim o książkach Eliadego wydawanych w Polsce w latach 90., takich jak Próba labiryntu. Rozmowy $z$ Claude-Henri Rocquetem (1992), Sacrum, mit, historia (1993), Mity, sny i misteria (1994), Sacrum i profanum (1996), Aspektymitu (1996), Inicjacja, obrzędy, stowarzyszenia tajemne (1997), do których wracam, czytając nie tylko dramaty Pałygi, ale także jego felietony pisane dla miesięcznika „Teatr” oraz rozmowy drukowane w „Dialogu”. Intelektualnym fundamentem dramaturgii polskiego twórcy wydaje się bowiem ontologiczna koncepcja sacrum, które w odróżnieniu od iluzorycznego profanum ludzkiej egzystencji „istnieje w sposób absolutny, niewzruszony, nie podlegający stawaniu się"3."Głód sacrum" to według Eliadego "tęsknota za by te m"4 i właśnie ku temu transcendują bohaterowie sztuk Pałygi. Dzieje się tak za sprawą odkrywanych przez nich znaków, symboli, archaicznych przekazów czy fragmentów zapomnianego (albo lekceważonego) rytuału, wobec nagłych h i e r o fa n i i piękna, mocy czy niesamowitości natury, w sytuacji cierpienia lub nagłej śmierci bliźniego. Eliade nie był wyłącznie religioznawcą, w swoich pracach występował przecież „ze znaczącymi twierdzeniami odnoszącymi się do człowieka i jego sytuacji egzystencjalnej, do ludzkiego sposobu istnienia w świecie i kondycji ludzkiej"5. Jako badacz dawnych kultur, a jednocześnie filozof, rewaloryzował w wyobraźni mieszkańców późnej nowoczesności archaiczne odczucie sacrum jako „świata mocnego, świeżego i czystego", pragnąc ożywić wrażliwość homo religiosus, dla którego „rzeczywiste” oznaczało

1 A. Pałyga Powrót bogów, Kraków 2017.

2 P. Passini, komentarz na okładce tomu Pałygi, tamże.

3 M. Eliade Traktat o historii religii, przeł. J. Wierusz-Kowalski, Opus, Łódź 1993, s. 42.

4 M. Eliade Sacrum. Mit. Historia. Wybór esejów, przeł. A. Tatarkiewicz, PIW, Warszawa 1993, s. 109.

5 A. Rega Człowiek w świecie symboli. Antropologia filozoficzna Mircei Eliadego, Nomos, Kraków 2001, s. 65. 
„święte”.„,Objawienie tego, co święte, ontologicznie ustanawia świat” - pisał w Sacrum i profanum ${ }^{6}$, a wpływ jego myśli na humanistów i artystów XX-wiecznych był ogromny?.

Nie sposób tego powiedzieć o ich współczesnych następcach, którzy tezy Eliadego traktują z rezerwą, jak baśniowe antidotum na kryzys zracjonalizowanej kultury Zachodu, a ten krytyczny trend dominuje także w polskim teatrze współczesnym. Młodzi, niezależni twórcy teatralni nawet nie przypuszczają, jak wiele „świętych" gór usypali i jak wiele teatralnych rytuałów odprawili ich poprzednicy w offowym teatrze lat 70., kiedy pierwsze tłumaczenia pism Eliadego trafiały do polskich księgarni. Właśnie $\mathrm{z}$ tej tradycji teatru antropologicznego, wyznaczanej takimi nazwiskami, jak Jerzy Grotowski i Włodzimierz Staniewski z teatru „Gardzienice”, wywodzi się Paweł Passini, który w komentarzu do tomu dramatów Pałygi napisał: „Wiele tekstów powstało w wyniku prób, aktorskich i muzycznych improwizacji, jakby Artur wydobywał je z plątaniny ciał, rytmu oddechów i dźwięku. Nie boi się metafory, rozsadza formy, ale - co najważniejsze - jest zawsze wyraziście obecny w swoich tekstach, przytomny i nieskończenie czuły"8. Na tle twórczości innych autorów pokolenia Pałygi jego poetyckie dramaty stanowią więc bardzo ciekawe odstępstwo od obowiązującej w dramacie i teatrze reguły zracjonalizowanego opisu świata, opartego na analizie dyskursów, a nie ludzkiego doświadczenia.

Powrót bogów jest zamierzoną prowokacją umysłu oświeconego przeprowadzoną ze świadomością pułapek, w jakie wpadają wyznawcy eliadyzmu pojmowanego w stylu łagodnego New Age. Mottem do pierwszej wersji Nieskończonej historii pisarz uczynił zdanie przepisane z Dzienników Sławomira Mrożka: „Jedno jest pewne: ból j e st”, którego nie należy czytać w duchu sentymentalizmu, ale egzystencjalizmu osadzonego w archaicznej ontologii. Ból stanowi najważniejszy składnik naszego człowieczeństwa, a zarazem paradoksalnie - daje nam udział w boskości, jako jedyny bowiem nie podlega iluzji wytwarzanej przez mózg. Mityczni bogowie wracają w sztukach Pałygi jako zagubiona przez człowieka naszych czasów realn o ść, a dzieje się

6 M. Eliade Sacrum i profanum: o istocie religijności, przeł. R. Reszke, Aletheia, Warszawa 1996, S. 16.

7 Polska recepcja pism Eliadego od początku lat 70. kształtowała także warsztat literaturoznawców, w szczególności badaczy romantyzmu. Por. B. Skarżyńska Mircea Eliade w Polsce. Recepcja religioznawczo-kulturowa, Neriton, Warszawa 2009.

8 P. Passini, komentarz na okładce tomu dramatów Pałygi. 
to poprzez doświadczenie cierpienia, którego zaskakującym źródłem jest ogień. Homo religiosus w dramatach autora Nieskończonej historii to człowiek w płomieniach.

\section{Punkt południe}

W Traktacie o historii religii Eliade napisał:

Z punktu widzenia mentalności człowieka archaicznego każdy początek stanowi illud tempus, gdyż zostawia „okno otwarte” na wielki czas, na wieczność. Marcel Mauss słusznie zauważył, że „sprawy religijne, które odbywają się w czasie, słusznie i logicznie uważa się za sprawy, które odbywają się w wieczności”. Istotnie, każda z tych „religijnych spraw” powtarza w nieskończoność archetyp, tzn. powtarza to, co działo się na „początku”, w chwili gdy dany ryt lub gest religijny został objawiony i jednocześnie ujawniony w historii. ${ }^{9}$

Dla Pałygi samo pisarstwo jest aktem mitotwórczym. Jego utwory mają tak oryginalny kształt, jak gdyby najważniejszą przyczyną ich powstania i główną zasadą funkcjonowania było stworzenie nowego języka: własnego, prywatnego języka dramatycznej poezji, która na poziomie pojedynczej frazy i kompozycji całego utworu pełni funkcję tajemnego szyfru. Jego złamanie staje się głównym zadaniem czytelnika, prowadzi do rozwiązania symbolicznej zagadki wpisanej w tekst. Tak pojęta lektura ma charakter inicjacyjny. Pałyga jest więc poetą dramatycznym w znaczeniu archetypowym, bo wynajdując własne, oryginalne środki ekspresji, w akcie kreacji artystycznej unieważnia czas i cofa się ku mitycznym początkom sztuki i samego istnienia. Komponując i dekomponując swoje tekstowe partytury do głośnego wykonania, pisze tak, , jakby był współczesny pierwszemu dniu Stworzenia”"10. Trudno jednoznacznie orzec, kiedy i gdzie rozgrywa się akcja jego utworów. Przestrzeń i czas multiplikują się w nich i mieszają w kolejnych monologach i dialogach, które raczej relacjonują zdarzenia, niż je przedstawiają, zazwyczaj podlegając komentarzowi narratora i chóru. Obie kategorie - przestrzeń i czas - tworzą ostatecznie mityczną jedność symbolizowaną przez „słońce”

9 M. Eliade Traktat o historii religii, s. 380.

10 M. Eliade Mity współczesnego świata, w: tegoż Mity, sny i misteria, przeł. K. Kocjan, Wydawnictow KR, Warszawa 1999, s. 30. 
południa, które jak ognisko ma swój „środek”, a gromadzący się w nim „popiół" jest skutkiem fizycznej przemiany ciał w energię i materii w ducha. Obie są funkcją świadomości autorskiej rozszczepianej na świadomość bohaterów dramatu, ludzi zupełnie różnych, ale pojednanych ze sobą granicznymi doświadczeniami narodzin i śmierci, zarazem początku i końca świata. Ich marzenie o przekroczeniu własnej kondycji, o chwili, kiedy między ludzkim "ja” a kosmosem na powrót powstaje boski stan nieoddzielenia, wyraża się w wypowiadanym na głos słowie, które ma sprawczą moc. Kwestia ciężarnej Magdy w finale Nieskończonej historii, padająca nad grobem zmarłej sąsiadki, z kluczową frazą: „Południe, myślę, mówię na głos”, doskonale wyraża tego rodzaju projekt dramatyczny:

Myślę, że dobrze mieć jakąś obsesję. Bo wtedy masz coś, co cię napędza. Ja nigdy nie miałam obsesji, nie mam i nie sądzę. Chyba bym się bała. Bałabym się. Strasznie bym się bała. No. Tak. Bo z drugiej strony człowiek przestaje odróżniać, co jest prawdziwe, co nie. Gubi się w domysłach. W ogóle nie potrafi nic oddzielić. Nic. Mówię do siebie, bo mnie uspokaja mój głos. Mój głos. Głos, głos, głos, głos. Czasami myślę, że mój głos jest jedyną rzeczą, jaką znam. Tak, jedyną rzeczą. No, tak, tak, tak, tak, tak. A jednocześnie, kiedy mówię na głos, wydaje mi się przecież obcy. Jakbym to nie ja. Wystarczająco obcy, żeby słuchać. Światło. Jasne. Wszystko roztapia się w świetle. Południe, myślę, mówię na głos. Jest południe."

Jedną z największych obsesji Artura Pałygi jest ogień. Wśród trzydziestu postaci Nieskończonej historii umieszcza Janka przede wszystkim po to, by za jego pośrednictwem zacytować fragment Robinsona Cruzoe i w ten sposób złożyć na kartach utworu autorską sygnaturę:

Któż nie domyśli się, że na drugi dzień rano pierwszą moją myślą było rozniecenie ognia. Co chwila budziłem się w nocy, bo mi szczęście spać nie dawało, a gdym zasnął, wciąż mi się śniło, że siedzę przed wielkim płomieniem. Od czasu zamieszkania na wyspie nie doświadczyłem takiej radości. $^{12}$ 
Najważniejszą figurą wyobraźni Pałygi jest pochylony nad ogniem szaman, którego praktyki ujawniają transcendentny wymiar rzeczywistości. Ciekawe jednak, że największymi „mocami” w jego dramatach dysponują kobiety: Dworniczkowa w Nieskończonej historii, Lucy w Środku słońca gromadzi siępopiół, Maria Skłodowska-Curie w monodramie W promieniach. Tę ostatnią Pałyga nazwie „czarownicą”.

\section{Paktz duchem}

W promieniach to poetycki monolog Marii Curie-Skłodowskiej, która jako adeptka wiedzy chemicznej pisze listy do siebie samej - dojrzałej już uczonej. Pisze, a w rzeczywistości (założonego performatywnego działania) listy te wypowiada. Biografia nowoczesnej badaczki przyjmuje pod piórem Pałygi kształt tajemniczego dialogu dziewczyny z kobietą, którą ma stać się w przyszłości, ale nie wskutek łaski czy niełaski innych ludzi, lecz wytężonej woli osoby pragnącej całkowicie zapanować nad swoim życiem. W noc osiemnastych urodzin młoda Maria przekracza nie tylko próg dojrzałości, ale też granicę swojej ludzkiej kondycji. W części zatytułowanej Uwięziona Mania myśli, mówi i czyni coś, co przywodzi na myśl sekretne ryty alchemików, magów i czarodziejów. W "gęstniejącym mroku" zapala zapałkę i przypieka sobie palce:

W moim świecie mam taki rytual.

Gra w ból. ${ }^{13}$

Maria wierzy, że jeśli zniesie ten ból, to otrzyma moc. Robi zatem coś niesamowitego - niczym szamanka nadaje fizycznemu zjawisku metafizyczne znaczenie, przez co jej doświadczenie przemienia się w akt duchowy. Maria mówi do płomienia, a płomień jej odpowiada. Dziewczyna żąda, by pojawił się przed nią ten sam, który pojawił się przed Faustem - Duch. „Otwarcie się na Ducha" także w jej przypadku oznacza "akces do Świata”, a słowo to Eliade zapisuje wielką literą, bo myśli o nieskończoności i wieczności ${ }^{14}$. Płomień pyta, czy jest na to gotowa, bo moc może ją zniszczyć. Tą mocą będzie promieniowanie nowych pierwiastków, radu i polonu, które rzeczywiście z czasem zabije Skłodowską, choć najpierw przyniesie jej sławę. Aluzyjnie przywołany

13 A. Pałyga Powrót bogów, s. 324.

14 M. Eliade Mefistofeles i androgyn, przeł. B. Kupis, Wydawnictwo KR, Warszawa 1994, s. 218. 
mit faustyczny osadzony jest tu w o wiele starszym wierzeniu i bardziej pierwotnym rytuale. Duch, który przychodzi do Fausta, to „mana”, boska siła, dzięki której doszło do stworzenia świata i dzięki której ten stworzony świat nadal istnieje, rozwija się, działa. Wszystko, „co jawi się człowiekowi jako skuteczne, twórcze, doskonałe"15, posiada mana. Przenoszą ją duchy, dusze zmarłych lub istoty nadprzyrodzone, trzeba jednak wejść z nimi w kontakt. W różnych tradycjach religijnych Wschodu "moce” bogów przejawiały się pod postacią płomieni, a wejście w kontakt $\mathrm{z}$ duchami oznaczało dla ascety wejście w ogień. Ciało ascety rozgrzewa się i poci. „Ciepło i ogień - tłumaczy Eliade - na planie fizjologii mistycznej wskazuje na przebudzenie mocy magiczno-religijnej"16. Moc ta jest niebezpieczna i pożądana głównie przez magów i wojowników, a więc tych, którzy chcą czynnie zmieniać rzeczywistość. Maria w utworze Pałygi jest „czarownicą”, która za pomocą odkrytego promieniowania chce dosłownie zmienić świat, i wojowniczką walczącą o wyzwolenie umysłów i kobiet.

Czemu służy mityzacja biografii Marii Skłodwoskiej-Curie? Pałyga pokazuje wyjątkowy moment w kulturze europejskiej, który najdobitniej wyraził chyba Fryderyk Nietzsche, pisząc w Wiedzy radosnej te słynne słowa „oszalałego człowieka":

Bóg umarł! Bóg nie żyje! Myśmy go zabili! Jakże się pocieszymy, mordercy nad mordercami? Najświętsze i najmożniejsze, co świat dotąd posiadał, krwią spłynęło pod naszemi nożami - kto zetrze z nas tę krew? Jakaż woda obmyć by nas mogła? Jakież uroczystości pokutne, jakież igrzyska święte będziemy musieli wynaleźć? Nie jestże wielkość tego czynu za wielka dla nas? Czyż nie musimy sami stać się bogami, by tylko zdawać się jego godnymi ${ }^{17 ?}$ ?

Performując z zapałkami w ręku monolog Marii, Pałyga ukazuje narodziny nowej religii, której bogiem staje się rozum, a dogmatem - nauka, w szczególności nauki przyrodnicze - chemia, fizyka, biologia. Kapłanami tej nowej religii będą uczeni, których pasja badawcza graniczy z „boskim szaleństwem" szamanów i czarowników. To oni wyrastają na współczesnych

M. Eliade Moc i świętość w historii religii, w: tegoż Mity, sny i misteria, s. 157.

16 Tamże, s. 180.

17 F. Nietzsche Wiedza radosna, przeł. L. Staff, Warszawa 1906-1907, sekcja 125, s. 168-169. 
„panów ognia”. Mit faustyczny odradza się więc w monodramie jako wielkie, pierwotne marzenie nowoczesnej uczonej, która pragnie udowodnić, że „istnieje coś jeszcze” - niewidzialne i piękne jak gwiazdy na nieboskłonie. Moment ukazania się promiennej poświaty nowo odkrytego pierwiastka to kolejna w tej dramaturgii h i e r o fa n i a:

W nocy poszliśmy do szopy.

Już z pewnej odległości było widać.

$[\ldots]$

Świecił.

Sam z siebie.

Nie odbitym światłem.

Nie siłą elektryczności.

Świecił sam z siebie, bo taka jest jego przyrodzona moc. ${ }^{18}$

Maria otrzymała moc - wiedzy, myśli, świadomości - i za jej pośrednictwem wyzwoliła moc jeszcze większą - promieniowanie. Jako „czarownica” zdaje sobie sprawę, że musi spalić siebie na ołtarzu nauki, i rozumie to zupełnie dosłownie - w jej umyśle następuje proces samospalenia, który przebiega na tej samej zasadzie, na jakiej odbywa się pierwotna ofiara szamana. Maria dosłownie „wciela świętość”, jak powiedziałby Eliade, i umiera „spalona”.

\section{Przeciw nicości}

Wśrodku słońca gromadzi siępopiół to najbardziej zagadkowa ze sztuk Pałygi, istny labirynt słów i sensów, którego pokonanie oznacza wtajemniczenie. Także w tym utworze motywy bólu i ognia tworzą wzór o „pradawnym” charakterze. Jego bohaterką jest kobieta, która spłonęła w pożarze, ale jej dusza okazała się nieśmiertelna. Lucy budzi się po agonii niczym pacjentka w szpitalu, pytając: "gdziejes / gdziejestem". Następujący potem dialog Iskierki i Płomyka rozgrywa się najpewniej w świadomości spalonej, natomiast akcja samego dramatu - jak wynika z prologu - w trzech miejscach jednocześnie, ale określenie "miejsce" nie ma w tym przypadku żadnego sensu, ponieważ troje bohaterów nie podlega przestrzennym ograniczeniom. Lucy pali się na balkonie w bloku, jest to "ostatni moment” jej życia, moment jak „błysk / kiedy wszystko jest jasne". Ekstremalne doświadczenie fizyczne - śmierć w płomieniach

18 A. Pałyga Powrót bogów, s. 329-330. 
- w jednej chwili zamienia się w ekstremalne doświadczenie duchowe. Nagłe uwolnienie Lucy z cierpiącego ciała poszerza jej świadomość i daje możliwość przekraczania granic dotąd nieprzekraczalnych - drzwi do mieszkania chorej na raka nauczycielki czy ciała sparaliżowanego chłopca. Jej „lot” pozwala nam zresztą obserwować i podsłuchiwać wielu innych bohaterów.

Lucy płonie na ósmym piętrze w bloku, do którego nie może podjechać wóz strażacki, na balkonie oddzielonym od innych rozgrzaną, uniemożliwiającą jakąkolwiek pomoc blachą. Lucy przez lata żyła jak skazaniec w celi śmierci, czekając na moment egzekucji. Pałyga chce nam tę egzekucję dokładnie pokazać, ale czyni to z perspektywy, która fizycznej torturze człowieka nadaje metafizyczny sens. Jego wyobraźnia znowu naprowadza nas na trop szamanów, którzy „przekroczyli kondycję ludzką i mają udział w kondycji duchów; jak duchy stają się niewidzialni, latają w przestworzach, wchodzą do Nieba, zstępują do Piekieł; wreszcie są odporni na ogień"19. Ale Lucy jest szamanką szczególnego rodzaju - jej lot odbywa się po śmierci rzeczywistej, a nie w trakcie ascetycznej praktyki. Bohaterka sztuki nie zwiedza też zaświatów, ale tkwi „w schronie po końcu świata” i jednocześnie penetruje rzeczywistość od tej jej strony, która dla ludzi oznacza bezradność, lęk, złość, ból, cierpienie, beznadzieję, rozpacz. To szamanka bolesnej kondycji człowieka, którą przekracza siła skupionej myśli samego pisarza. Pałyga mierzy się więc z problemem śmierci we współczesnym świecie, który utożsamił ją $\mathrm{z}$ nicością. Dramat inicjuje w nas nowy rodzaj świadomości, która polega nie na reaktywacji dawnych wierzeń czy bogów, ale na konsekwentnym wyborze bytu przeciw nicości. Za każdym razem, gdy wyrażana w monologach świadomość osuwa się w rejony ontologicznego nihilizmu - negacji samego bytu - Pałyga wyznacza przeciwny punkt widzenia. Najdobitniej dostrzegamy to w finale utworu, gdy mowa o zjawisku zbiorowej halucynacji, której ulegli obserwatorzy pożaru. Wszyscy twierdzili, że kobieta na balkonie miała na sobie czerwoną sukienkę, podczas gdy nikt nigdy wcześniej nie widział jej tak ubranej. Iskierka wyjaśnia, że chodzi tu o efekt zwany „theatri”. W labiryntowym tekście dramatu pojawiają się dwa przykłady tego zjawiska: kiedy marynarze wyruszyli na ratunek rozbitkom, ale zamiast widocznej wcześniej tratwy znaleźli tylko suche gałęzie, i kiedy dwaj oddaleni od siebie himalaiści usłyszeli przebój zaśpiewany przez łączącą ich linę. Już po KOŃCU, w epilogu dramatu, Lucy podważa koncepcję świata jako zbiorowego złudzenia,

19 M. Eliade Tęsknota za rajem w tradycjach prymitywnych, w: tegoż Mity, sny i misteria, s. 86. 
platońskiej iluzji, wspólnej projekcji czy kosmicznego hologramu, który absorbuje świadomość ludzi:

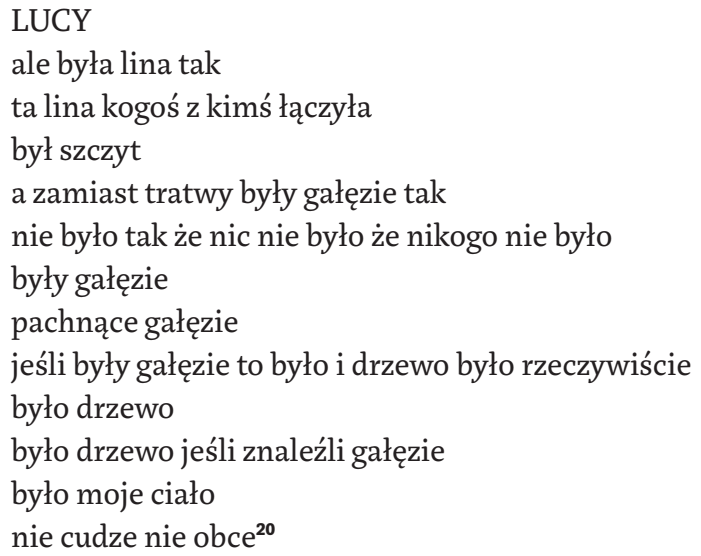

Żywioł ognia, w którym właśnie ginie bohaterka, to w dramacie Pałygi przede wszystkim żywioł myśli, która jak u Heraklita stale wybucha nowym płomieniem i trawi wszystko - także zwątpienie.

\section{Empatia}

Mimo stale podsycanej autorskiej „obsesji” w sztuce Powrót bogów symbolem sacrum nie będzie ogień - w całym dramacie nie ma ani jednego płomienia! „Po południu”, czyli po katastrofie, świat odradza się za sprawą cichej wegetacji roślin, które ze sobą rozmawiają „bezpośrednio”, a więc całkowicie intuicyjnie, na poziomie współodczuwających serc i umysłów, niczym ludzie uwolnieni od lęku i agresji z jednej, i narzuconych sobie konwencji - z drugiej strony. Szaman potrafi rozmawiać z roślinami i zwierzętami, „uczestniczyć w ich tajemnicach i cieszyć się pełnią ich życia"21. W świecie Bzu Czarnego, Mahonii Ostrolistnej, Jarzębia Szwedzkiego, Skrzydłokwiata nie ma człowieka historycznego, dlatego gaśnie tu ognisty żywioł myśli i dążenia, a wraz z nim ustają „szlochy” i „krzyki”, zakwita za to pleniąca się natura:

\footnotetext{
20 A. Pałyga Powrót bogów, s. 211.

21 M. Eliade Tęsknota za rajem w tradycjach prymitywnych, s. 78.
} 


\section{BEZ CZARNY}

Spokój

MAHONIA OSTROLISTNA

Cisza

BEZ CZARNY

I nikt nie zapłacze

MAHONIA OSTROLISTNA

I jest dzień. I jest jasno.

JASTRZĄB

I jest po południu. ${ }^{22}$

Prolog do dramatu nosi tytuł Park wieczny - nie las, lecz park, a więc miejsce, w którym rośliny podlegają specjalnej trosce, w ich kompozycji, a nawet kształcie znać zamysł ogrodnika. Park to w sztukach Pałygi miejsce wyjątkowe. Jakub z Nieskończonej historii właśnie tam zaczął czytać swojego Gilgamesza, zdając sobie sprawę, że „W tym parku, przy tej rzece, za chwilę odebrany zostanie sygnał sprzed tysięcy lat, z nieistniejącej już cywilizacji”23. Do parku poszła Judyta, aby rozmyślać o śmierci Dworniczkowej - i właśnie tam się zakochała. Park jest miejscem prywatnych hierofanii, czas w nim znika, a rzeczywistość wzmaga się w swojej realności. Dzieje się to stale i niezmiennie, kiedy więc Mahonia Ostrolistna wspomni o jakimś „przedparku”, Bez Czarny natychmiast ją skoryguje: „Przedpark nie istnieje. Park był zawsze” ${ }^{24}$. Rośliny kiełkują, rosną i obumierają, mimo to czas dla nich nie istnieje, bo w każdej odradza się poprzednia i w niej żyje. Prosty dialog roślin odsłania sens fenomenologicznie pojmowanego archetypu, którego koncepcję Eliade kształtował zainspirowany ideą prarośliny (Urpflanze) Goethego. Pierwotna, pierwsza praroślina „porządkuje i integruje (jako wspólne źródło) wszystkie gatunki roślin występujące w przyrodzie”25. „W skromniejszej proporcji i bez popadania w ekstazę, jak Goethe z okazji swojego odkrycia, także ja doznałem szczególnego przeżycia, kiedy zrozumiałem, że formy »historyczno-religijne« są tylko niezliczonymi odmianami ekspresji kilku fundamentalnych przeżyć 
religijnych" - pisał Eliade w swoim dzienniku ${ }^{26}$. „To jest boskie” - napisze Pałyga o odczuwanym przez siebie tajemniczym sposobie komunikowania się roślin. Zatem obecność jakiego boga zdradza dramat?

Jego imię wymieni Ojciec, a domyślamy się w tej postaci opiekuna sparaliżowanego chłopca, którego w innym dramacie Pałygi odwiedziła płonąca Lucy. Poprzednio mężczyzna wymyślał własny system komunikacji z synem za pomocą płyty gramofonowej i sztuczek z alfabetem. Odczytując w nieskończoność nic nieznaczący układ liter, popadał w obłęd współczesnego racjonalisty, który $\mathrm{w}$ dążeniu do porozumienia $\mathrm{z}$ chorym dzieckiem całkowicie tracił z nim kontakt. Teraz Ojciec pogodził się z „roślinną” kondycją sparaliżowanego, a gdy tylko to uczynił, natychmiast dostrzegł w niej ślad najważniejszej, ,boskiej” siły przenikającej całe stworzenie. Zanim do świata mówiących roślin wtargnie ludzki potwór (a już tam zmierza, prowadzi go Tezeusz), zanim opętane bachantki rozerwą na strzępy swoje dzieci, a „Mięsna piosenka" ponownie stanie się hymnem ludzkości, powracającym bogiem okazuje się e mpatia:

OJCIEC

byłem szufladą szafą stołem byłem krzesłem

to było potrzebne

to zawsze początkowo wygląda na żart niepoważnie

ale efekty są porażające

na przykład bycie krzesłem to nie że cztery nogi i oparcie

nie

ale że jestem zbiorem składowych które się składają na krzesło

drzewo które jeszcze rosło które jeszcze żyje farba lakier metalowe gwoździe

wszystko to składa się na mnie w sposób dosyć sztuczny i obcy mi jako każdej ze składowych

połączony arbitralnie i bez mojej woli jestem bytem dla samego siebie całkiem absurdalnym

i wchodzi się głębiej

w substancje w mikrobyty które składają się na nogę od krzesła na

farbę

składowe składowych

26 M. Eliade Religia, literatura i komunizm. Dziennik emigranta, przeł. A. Zagajewski, Puls, Warszawa 1990, s. 226-227. 
a wszystko jest w ruchu

wszystko jest mrowiskiem

to są rzeczy które powinno się mówić nie słowami ale

musieliby wszyscy stać się czującymi krzesłami

albo łóżkami

jak mój syn ${ }^{27}$

Czuwając przy synu, Ojciec chce go „odczuć”, tak jak syn odczuwa łóżko. Myśl o wzajemnym „współodczuwaniu” prowadzi Ojca ku tym „osobom i świadomościom”, które „dyżurują”, to znaczy opiekują się „niedyżurującymi”, bo chorymi, słabymi, potrzebującymi opieki, a następnie ku temu, który „wyznacza dyżury” - „bo jeśli nikt nic nie ma żadnego znaczenia”. Wtedy można zrobić wszystko, nawet zabić własnego syna. Pojawia się więc trwoga, ale na szczęście istnieje także wybór, jest „albo-albo”. Zamiast „wyjść i udusić kogokolwiek” albo „wstać i pójść sobie”, można „położyć się obok ciebie i stać się jak ty". Stać się rośliną, która nie mówi, nie działa, nie myśli, ale zapamiętuje „zły dotyk dobry dotyk” i nie wiadomo, „czym”, bo przecież „nie rozumem”. Więc w jaki sposób?

\section{OJCIEC}

jest wielka siła

która się naukowo nazywa empatią

że można się wczuć w kogoś w coś

nawet w siebie

nawet się można wczuć w siebie to ciekawe

wczuć czyli czuć się

czuć się kim czymś

czyli być kimś czymś

i to jest naprawdę ${ }^{\mathbf{2 8}}$

\section{Copowiedziałpłomień}

Reaktywując mityczne struktury postrzegania i rozumienia świata, Pałyga - szaman polskiego dramatu - roznieca w swoich „rytualnych scenariuszach" żywy ogień. Stale krążąc wokół motywów iskry, ognia, płomieni, żaru

27 A. Pałyga Powrót bogów, s. 225.

28 Tamże, s. 227. 
słonecznego, promieniowania, śledzi ukryte trwanie mitu w zracjonalizowanej kulturze późnej nowoczesności, sprawdza jego poznawczą skuteczność w świecie „opuszczonym przez bogów”, pyta o możliwość ich „powrotu”, czyli przede wszystkim odnowienia utraconego poczucia realności istnienia w świecie iluzji wytwarzanej przez ludzki umysł (wspomagany dziś przez technologie). Właśnie tak autor Nieskończonej historii rozumie opozycję między utraconym sacrum a wszechobecnym, multiplikowanym przez wirtualne projekcje profanum naszej współczesności. Ogień niszczy iluzję, wprowadza w realność i w ten sposób zyskuje wartość symbolu dynamicznie związanego z takimi aspektami ludzkiego doświadczenia, jak ból fizyczny, cierpienie, umartwienie, śmiertelna transgresja z jednej i wola, dążenie, poznanie, świadomość, myślowa transgresja z drugiej strony. Ogień wyraża marzenie o nieśmiertelności i wiarę w absolutny wymiar bytu; zwiastując koniec i zmianę, staje się symbolem katastrofy, podczas gdy wilgoć zapowiada w sztukach Pałygi wielki naturalny początek świata, jego odrodzenie. Ogień jest duszą i samą myślą, która pokonuje wszelkie granice - także granice sparaliżowanego ciała. Niezmienna, „roślinna” obecność człowieka bez świadomości odnawia z kolei moc empatii jako najważniejszej zasady życia - i twórczości dramatycznej. Pałyga, tak jak bohater jego sztuki, mógłby powiedzieć: „mogę w ciebie wejść tobą stać się i zrozumieć", i to bez przypalania zapałkami żywego ciała... Ludzi jednoczy nie tylko ból, ale także czułe skupienie na wszystkim, co ożywione i nieożywione. W mikroświecie „czujących łóżek” bogiem jest pewny swego istnienia człowiek i właśnie jego "powrót” przepowiada Pałyga. 


\section{Abstract}

\section{Jacek Kopciński}

THE INSTITUTE OF LITERARY RESEARCH OF THE POLISH ACADEMY OF SCIENCES (WARSAW)

Humans in Flames: Arthur Pałyga's Mythical Imagination

Kopciński discusses the work of Polish playwright Artur Pałyga (b. 1971), especially Powrót bogów [The Return of the Gods, 2017], a collection of plays that draw on different poetics (oratorium, dramatic poem, mysterium, poetic monodrama). For Pałyga, the source of the gods' return is not tradition or history but the human need to encounter the non-human - the archaic myth reactivated in the characters' liminal situations (death, disease, selfsacrifice, spiritual loneliness), as well as the playwright's experience of trying to identify with the speaker of a dramatic text. Kopciński suggests that Pałyga's characters strive towards a form of absolute being that recalls the notion of the sacred proposed by historian of religion Mircea Eliade (1907-1986). The archaic symbol connecting the characters' experience is fire (flame, spark, solar heat, lethal radiation). Kopciński's analysis of Pałyga's mythical imagination focuses on the transformations of this symbol.

\section{Keywords}

drama, myth, imagination, sacred, profane, symbol, fire, Mircea Eliade 